\title{
Genotoxic damage in Solea senegalensis exposed to sediments from the Sado Estuary (Portugal): Effects of metallic and organic contaminants
}

\author{
Pedro M. Costa ${ }^{\mathrm{a}, *}$, Jorge Lobo ${ }^{\mathrm{a}}$, Sandra Caeiro ${ }^{\mathrm{a}, \mathrm{b}}$, Marta Martins ${ }^{\mathrm{c}}$, Ana M. Ferreira ${ }^{\mathrm{c}}$, \\ Miguel Caetano ${ }^{c}$, Carlos Vale $^{c}$, T. Ángel DelValls ${ }^{d}$, Maria H. Costa ${ }^{a}$ \\ a IMAR - Instituto do Mar, Departamento de Ciências e Engenharia do Ambiente, Faculdade de Ciências e Tecnologia da Universidade Nova de Lisboa, \\ 2829-516 Monte de Caparica, Portugal \\ ${ }^{\mathrm{b}}$ Departamento de Ciências Exactas e Tecnológicas, Universidade Aberta, Rua da Escola Politécnica, 141, 1269-001 Lisboa, Portugal \\ c IPIMAR - INRB, Instituto Nacional dos Recursos Biológicos, Avenida de Brasilia, 1449-006 Lisboa, Portugal \\ d UNESCO/UNITWIN/WiCop Chair, Departamento de Química Física, Facultad de Ciencias del Mar y, Ambientales, Universidad de Cádiz, Polígono río San Pedro s/n, \\ 11510 Puerto Real, Cádiz, Spain
}

\section{A R T I C L E I N F O}

\section{Article history:}

Received 21 November 2007

Received in revised form 14 March 2008

Accepted 20 April 2008

Available online 30 April 2008

\section{Keywords:}

Genotoxicity

Erythrocyte nuclear abnormalities

Comet assay

Solea senegalensis

Contaminated sediments

Sado Estuary

\begin{abstract}
A B S T R A C T
Juvenile Solea senegalensis (Senegalese sole) were exposed to freshly collected sediments from three sites of the Sado Estuary (West-Portuguese coast) in 28-day laboratory assays in order to assess the ecological risk from sediment contaminants, by measuring two genotoxicity biomarkers in peripheral blood: the percentage of Erythrocyte Nuclear Abnormalities (ENA) by use of an adaptation of the micronucleus test, and the percentage of DNA strand-breakage (DNA-SB) with the Comet assay. Sediments were surveyed for metallic ( $\mathrm{Cr}, \mathrm{Ni}, \mathrm{Cu}, \mathrm{Zn}, \mathrm{As}, \mathrm{Cd}$ and $\mathrm{Pb}$ ) and organic (PAHs (polycyclic aromatic hydrocarbons), PCBs (polychlorinated biphenyls) and DDTs (dichloro-diphenyl-trichloroethane)) contaminants. Sediments from site $\mathrm{A}$ (farthest from hotspots of contamination) were found to be the least contaminated and weaker inducers of genotoxic damage, whereas sediments from sites B (urban influence) and C (affected by industrial effluents and agricultural runoffs) were responsible for a very significant increase in both ENA and DNA-SB, site $\mathrm{B}$ being most contaminated with metals and site $\mathrm{C}$ mainly with organic pollutants, especially PAHs and PCBs . Analysis of genotoxic effects showed a strong correlation between the concentrations of PAHs and PCBs and both biomarkers at sampling times $\mathrm{T}_{14}$ and $\mathrm{T}_{28}$, while the amounts of $\mathrm{Cu}, \mathrm{As}, \mathrm{Cd}$ and $\mathrm{Pb}$ were less strongly correlated, and at $\mathrm{T}_{28}$ only, with ENA and DNA-SB. These results show that organic contaminants in sediment are stronger and faster acting genotoxic stressors. The results also suggest that metals may have an inhibitory effect on genotoxicity when interacting with organic contaminants, at least during early exposure. ENA and DNA-SB do not show a linear relationship, but a strong correlation exists between the overall increase in genotoxicity caused by exposure to sediment, confirming that they are different, and possibly non-linked effects that respond similarly to exposure. Although the Comet assay showed enhanced sensitivity, the two analyses are complementary and suitable for the biomonitoring of sediment contaminants in a benthic species like S. senegalensis.
\end{abstract}

(c) 2008 Elsevier B.V. All rights reserved.

\section{Introduction}

The presence of DNA and chromosome damage and the efficacy of damage repair have gained growing concern regarding toxic substances, since they are not only directly linked to cell survival but also to mutagenesis and carcinogenesis. Many environmental contaminants are known to induce damage to chromosomes and DNA, and genotoxicity has been integrated in biomonitoring programs to

\footnotetext{
* Corresponding author. Tel.: +351 212948 300x10103; fax: +351 212948554 .

E-mail address: pmcosta@fct.unl.pt (P.M. Costa).
}

assess exposure to xenobiotics. Much research is now being focused on human populations exposed to contaminants (e.g., workers in health-hazardous industries $[1,2]$ ) and to animal species living in potentially contaminated environments. For such purposes, a series of genotoxicity assessment assays has been developed and is frequently applied and put to test in a wide range of organisms, from the classic micronucleus (MN) test to the agarose gel DNA strandbreakage assay, the single-cell gel electrophoresis (Comet) assay and the analysis of xenobiotics-DNA adducts. The employment of these techniques has become widespread among toxicologists involved in research at different levels: from biomedicine to environmental sciences. 
The analysis of erythrocyte nuclear abnormalities (ENA) comprises a variant of the standard micronucleus test and is widely used in fish toxicology. In this assay, a number of alterations in cell nuclei that may lead to their fragmentation and/or to micronucleus formation are recorded instead of counting the micronuclei themselves, which are rare and frequently measured by subjective scoring [3-6]. Although originally applied to human health issues, ENA analysis and the MN test have become rather common as simple tests for genotoxicity of organic and metallic contaminants in fish, since fish erythrocytes are nucleated $[3,7,8]$. There are many other classical tests in fish blood cells that have become widespread due to their simplicity and feasibility, such as analyses of membrane permeability and cell shape [9].

The alkaline version of the Comet assay has become a common technique for detection of DNA damage (chain-fragmentation) resulting from the combination of single- and double-strand breaks as well as alkali-labile sites (formed by excision of damaged nucleobases) and xenobiotic-DNA adducts that break during electrophoresis [10]. The Comet assay has been proposed as an effective tool for biomonitoring organic contaminants like pesticides and their derivatives [11], metals such as cadmium [12] and for the monitoring of waters contaminated with complex mixtures [13].

The employment of a both ENA and Comet assay for genotoxicity assessment in fish has been proposed before, since they are related to different levels of degradation of genetic material: ENAs reflect chromosome-level genotoxicity, whereas the alkaline Comet assay allows assessment of DNA damage at the molecular level [14] through quantification of total strand-breaks. It is noteworthy, though, that genotoxicity assays have mainly focused on in vitro tests for the effects of isolated contaminants in a specific cell population (e.g., fish hepatocytes and mammalian lymphocytes), or in vivo assays of waterborne isolated or (few) mixed contaminants. Recently, research has begun to focus on genotoxic effects in fieldcollected aquatic animals and on assays with sediments using fish and aquatic invertebrates. Nevertheless, most of these studies deal with one or a limited number of contaminants and thus research is still missing concerning the relative potency of different types of contaminant in inducing damage in chromosomes or DNA, and concerning the genotoxic effects of a complex mixture of different kinds of contaminant, such as in sediments in general and in estuarine sediments in particular.

The Sado Estuary is one of the largest estuarine areas in Europe. It is subject to a large variety of anthropogenic usages and alterations that often collide: while a large part of the estuary is classified as a natural reserve and the Tróia Peninsula is an important tourism and leisure area, the city of Setúbal has one of the largest heavy-industry concentrations in Portugal, including mineral-ore deployment facilities, chemical plants, paper mills, shipyards and a large thermoelectrical unit. The estuary is also very important for fisheries and aquaculture, which together represent a large portion of the local society's income and economy. For these reasons, efforts have been made to establish risk-assessment strategies in the estuary, which involve analysis of contaminants [15] and biomarker approaches using bioassays [16].

Solea senegalensis Kaup, 1858 (Pleuronectiformes: Soleidae) is a very common benthic fish species in the Sado Estuary where, together with other flatfish, it is a regular target or at least a valuable by-catch for local fisheries. Reproductive adults enter the estuary for reproduction in the summer, and as a consequence, the population reaches the highest number of individuals in the autumn [17]. This species inhabits sandy or muddy bottoms and scavenges the sediment for feeding on small benthic invertebrates like polychaetes, amphipods and bivalves [18,19]. S. senegalensis may be exposed to sediment contaminants by foraging on benthic fauna and also by direct contact (e.g., through gill epithelia) with sediment particles or interstitial water. The benthic nature of the species and the fact that it is a very common species along the Atlantic coasts of the Iberian Peninsula render S. senegalensis particularly interesting with respect to bio-monitoring of sediment contaminants in the Peninsula [20].

The main goals of the present work are (i) assessment of genotoxicity biomarkers in a benthic fish as an effective tool for biomonitoring sediment contaminants, (ii) to compare the relative potency of sediment metallic and organic contaminants in terms of genotoxic effects, and (iii) to compare two different genotoxicity indicators: ENA and total DNA strand breakage (DNA-SB).

\section{Methods and materials}

\subsection{Experimental assay}

The sediments to be tested were collected from three sites of the Sado Estuary (Fig. 1). Station A is located near an environmentally protected area, and is the farthest from direct contamination sources. Due to its geographical location in the estuary, this site has comparatively stronger influence from ocean hydrodynamics and shorter water residence time than the other sites. Site B, near the port of Setúbal, and site C, just off the city's heavy-industry area, were surveyed as potentially contaminated. They are located in an area of lower hydrodynamics and stronger river influence, which facilitates retention of contaminants and smaller sediment particles.

Sediment collection was made near the shore, at a maximum depth of $9 \mathrm{~m}$, in November 2006. Freshly collected sediments were used in the assays and homogenized portions were immediately frozen for subsequent analyses.

Juvenile hatchery-brood and laboratory-reared $S$. senegalensis belonging to the same cohort ( $69 \pm 6 \mathrm{~mm}$ standard length), obtained from aquaculture research facilities (IPIMAR/CripSul-Estação Piloto de Piscicultura, Olhão, Portugal), were randomly distributed in aerated tanks (capacity, $15 \mathrm{~L}$ ) each containing $2 \mathrm{~L}$ of sediment $\left(525 \mathrm{~cm}^{2}\right.$ of sediment surface) and 12 L of water, with 24 animals being allocated per tank. Sediments were allowed to settle for $48 \mathrm{~h}$ prior to the beginning of the assay. The 28 -day dynamic, assays were performed in duplicate, with three sampling times: day $0\left(\mathrm{~T}_{0}\right)$ day $14\left(\mathrm{~T}_{14}\right)$ and day $28\left(\mathrm{~T}_{28}\right)$. Fish were fed daily with Aquasoja M2 commercial fish pellets (Sorgal, Ovar, Portugal). Water parameters ( $\mathrm{pH} 7.9 \pm 0.2$, salinity $=33 \pm 1$, temperature $=18 \pm 1{ }^{\circ} \mathrm{C}, \mathrm{DO}_{2}=40-45 \%$, and total ammonia $\left.=2-4 \mathrm{mg} \mathrm{L}^{-1}\right)$ were monitored and held constant for all tests through weekly water changes ( $25 \%$ of the total volume) in order to mimic rearing conditions.

\subsection{Sediment analysis}

Sediments were surveyed for fine fraction (FF), total organic matter (TOM) and redox potential (Eh) since genotoxicity may be influenced not only by the

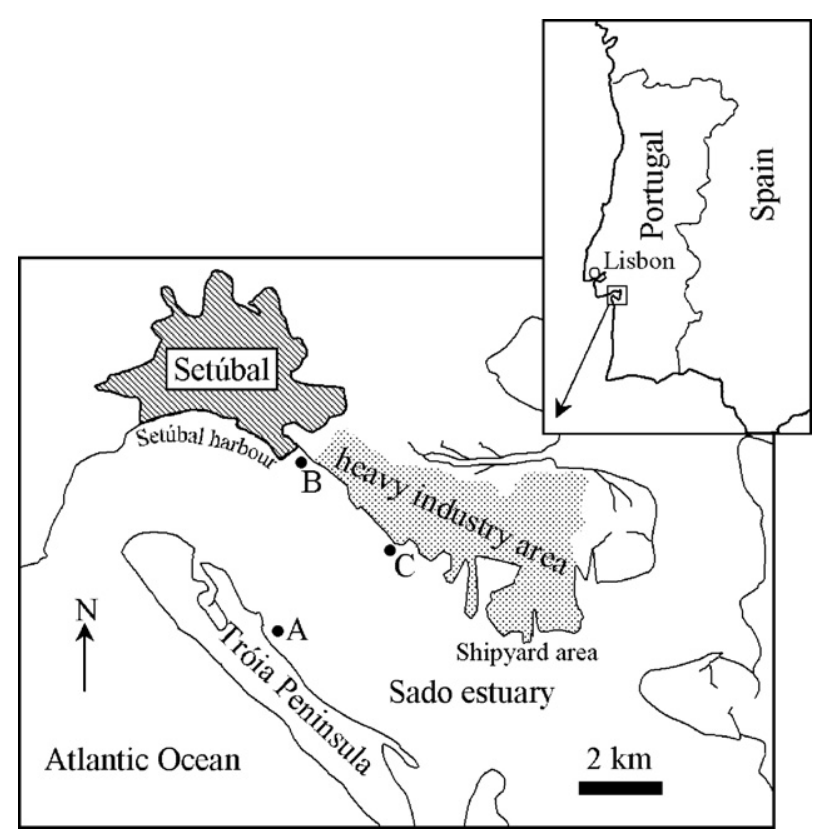

Fig. 1. Map of the study area with sediment collection sites ( 
contaminants' concentration but also by sediment parameters influencing their bioavailability. $\mathrm{FF}$ (particle size $<63 \mu \mathrm{m}$ ) was obtained by removal of organic matter with $\mathrm{H}_{2} \mathrm{O}_{2}$, followed by disaggregation with pyrophosphate, washing and hydraulic sieving. Results are expressed as percentage FF of the total dry weight (DW) of the sediment. Sediment TOM was quantified by total ignition at $500 \pm 25^{\circ} \mathrm{C}$ for $4 \mathrm{~h}$ Results are expressed as percentage TOM relatively to sediment DW. Sediment Eh was measured immediately following collection, using an Orion model $20 \mathrm{~A}$ meter with a $\mathrm{H} 3131 \mathrm{Ag} / \mathrm{AgCl}$ reference electrode (Orion Research Inc.). Sediment samples were oven-dried to constant weight prior to determination of TOM, FF and contaminant concentrations in order to express results relatively to sediment DW.

Sediments were surveyed for the metals chromium $(\mathrm{Cr})$, nickel $(\mathrm{Ni})$, $\operatorname{copper}(\mathrm{Cu})$ cadmium ( $\mathrm{Cd})$, lead $(\mathrm{Pb})$ and zinc $(\mathrm{Zn})$ and the metalloid arsenic (As). Approximately $100 \mathrm{mg}$ of sediment was completely mineralized with $6 \mathrm{~mL} \mathrm{HF} \mathrm{(40 \% ,v/v)}$ and $1 \mathrm{~mL}$ of Aqua-Regia $\left(36 \% \mathrm{HCl}\right.$ and $60 \% \mathrm{HNO}_{3} ; 3: 1 \mathrm{v} / \mathrm{v}$ ) in closed Teflon vessels at $100^{\circ} \mathrm{C}$ during $1 \mathrm{~h}$. The contents were evaporated to near dryness in Teflon vials, redissolved in $\mathrm{HNO}_{3}$, heated for $20 \mathrm{~min}$ at $75^{\circ} \mathrm{C}$ and diluted to $50 \mathrm{~mL}$ with Milli-Q water [21]. Concentrations of $\mathrm{Cr}, \mathrm{Ni}, \mathrm{Cu}, \mathrm{Zn}, \mathrm{As}, \mathrm{Cd}$ and $\mathrm{Pb}$ were determined using a quadropole inductively coupled plasma mass spectrometer (ICP-MS) (Thermo Elemental, X-Series) equipped with a Peltier Impact bead spray chamber and a concentric Meinhard nebulizer. A seven-point calibration curve in the range between 1 and $100 \mu \mathrm{g} \mathrm{L}^{-1}$ was used to quantify metal concentrations. Variation coefficients for metal readings ranged between 0.5 and $2 \%$. Method accuracy was determined by analysis of procedural blanks and sediment reference materials: MESS-2 (NRC, Canada), PACS-2 (NRC, Canada) and MAG-1 (USGS, USA) and metal concentrations were found within the certified range. Results are given in $\mathrm{mg} \mathrm{kg}^{-1}$ sediment DW.

PAHs (polycyclic aromatic hydrocarbons) were analysed from dried sediments spiked with $1 \mathrm{~mL}$ surrogate standards (SUPELCO) containing acenaphthene-d10 $\left(0.408 \mu \mathrm{g} \mathrm{mL}^{-1}\right)$, pyrene-d10 $\left(0.397 \mu \mathrm{g} \mathrm{mL}^{-1}\right)$, chrysene-d12 $\left(0.397 \mu \mathrm{g} \mathrm{mL}^{-1}\right)$ and perylene-d12 $\left(0.433 \mu \mathrm{g} \mathrm{mL}^{-1}\right)$ and Soxhlet-extracted with $250 \mathrm{~mL}$ of a mixture of acetone and hexane $(1: 1, \mathrm{v} / \mathrm{v})$ for $36 \mathrm{~h} \mathrm{[22]}$. The extract was concentrated by evaporation and fractionated with a silica-alumina (1:1) column. PAH compounds were then eluted with hexane/dichloromethane ( $9: 1$ and 4:1, v/v) and evaporated. Determination of PAHs was performed on a GCQ trace Finnigan gas chromatography-mass spectrometry (GC-MS) system in selected ion monitoring (SIM) mode. An autosampler and DB-5 column $(30 \mathrm{~m}, 0.25 \mathrm{~mm}, 0.25 \mu \mathrm{m})$ were used. Identification of PAH compounds was based on the comparison of their GC-retention times and their mass spectrum, with appropriate individual standards. Concentrations of individual PAHs were measured by the internal standard peaks area method and a nine-point calibration curve for each compound. The detection limit was calculated with a signal-to-noise ratio of 3:1 in a blank sample $(n=5)$ and varied within a narrow interval around $0.001 \mathrm{Mgg}^{-1}$. Results are expressed in $\mathrm{ng} \mathrm{g}^{-1}$ sediment DW. Total PAH ( $\mathrm{tPAH}$ ) means the sum of all analysed compounds.

PCB (polychlorinated biphenyls) and DDT (dichloro-diphenyl-trichloroethane) determinations in sediments were carried out in dry sediment samples that

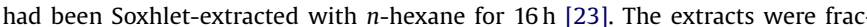
tionated with a Florisil chromatographic column. PCBs and pp'DDE were eluted with $15 \mathrm{~mL}$ of $n$-hexane and pp'DDD and pp'DDT were eluted with $45 \mathrm{~mL}$ of dichloromethane/hexane $(30: 70, \mathrm{v} / \mathrm{v})$. The extracts were purified with sulphuric acid and the elemental sulphur was removed with activated copper. PCB congeners and pp'DDT plus metabolites (pp'DDD and pp'DDE) were analysed using a HewlettPackard 6890 gas chromatograph with an electron-capture detector and a capillary column (DB5, J\&W, $60 \mathrm{~m}$ ). Quantification was obtained by the external standard method, using a seven-point calibration curve for each compound. In the present study tPCB means the sum of congeners with IUPAC numbers and tDDT means the sum of pp'DDT, pp'DDD and pp'DDE metabolites. Concentrations are given in $\mathrm{ng} \mathrm{g}^{-1}$ sediment DW. The analytical detection limit was $0.01 \mathrm{ng} \mathrm{g}^{-1}$.

Quality control for organic contaminants was obtained by analysis of the certified sediment SRM 1941b (NIST, USA) and blanks, included in each batch of 12 samples. Recoveries of analysed PAHs in the certified material ranged from 73 to $112 \%$, and from 93 to $109.2 \%$ for PCBs and DDTs.

\subsection{Genotoxicity assessment}

Genotoxic effects were assessed by the alkaline version of the single-cell gel electrophoresis (Comet) assay and ENA analysis in fish peripheral blood. Blood was collected from 12 animals per test and per sampling time ( 6 per replicate) just above the lateral line system with a syringe previously washed with 0.1 M EDTA to prevent clotting. Blood aliquots were immediately smeared on glass microscopy slides for ENA analysis and diluted in cold $50 \mathrm{mM}$ PBS (phosphate-buffered saline) with $0.7 \%$ $\mathrm{NaCl}$, pH 7.4 (dilution factor: 200) for the Comet assay, which was performed right after blood collection to ensure maximum cell viability.

ENA analysis was performed by staining methanol-fixed ( $15 \mathrm{~min}$ ) blood smears with $0.1 \mathrm{~g} \mathrm{~L}^{-1}$ acridine orange (Sigma; maximum absorbance at $488 \mathrm{~nm}$ ). Slides were afterwards mounted with DPX (from BDH) [6]. About 1000 mature erythrocytes per slide were observed in order to determine the percentage of cells with nuclear abnormalities. The ENA considered were: micronuclei, nuclear buds, polynucleated cells and fragmenting nuclei $[6,24]$. Results are expressed as the percentage of mature erythrocytes showing nuclear abnormalities.
Table 1

Characterization of the test sediments

\begin{tabular}{llcl}
\hline Site & FF $(\%)$ & TOM $(\%)$ & Corrected Eh $(\mathrm{mV})$ \\
\hline A & 37.3 & 3.2 & -233 \\
B & 97.9 & 11.8 & -290 \\
C & 76.8 & 7.7 & -316 \\
\hline
\end{tabular}

The Comet assay [10] was performed with $10 \mu \mathrm{L}$ of cell suspension in PBS diluted in $180 \mu \mathrm{L}$ of liquid $\left(35-40^{\circ} \mathrm{C}\right) 1 \%(\mathrm{w} / \mathrm{v})$ low melting-point agarose (LMPA; Sigma) in PBS. Aliquots $(2 \times 75 \mu \mathrm{L})$ of cell-containing LMPA were placed on slides pre-coated with $1 \%(\mathrm{w} / \mathrm{v})$ normal melting-point agarose in TAE buffer (dried for at least $24 \mathrm{~h}$ ) and covered with a coverslip. After agarose solidification $\left(15 \mathrm{~min}, 4^{\circ} \mathrm{C}\right)$ the coverslip was removed and the slides were dipped for $1 \mathrm{~h}$ at $4{ }^{\circ} \mathrm{C}$ in lysis solution $(2.64 \% \mathrm{NaCl}$ $(\mathrm{w} / \mathrm{v}), 3.72 \%$ EDTA $(\mathrm{w} / \mathrm{v})$ and $5 \mathrm{mM}$ TRIS) to which was added $10 \%(\mathrm{v} / \mathrm{v})$ DMSO and $1 \%(\mathrm{v} / \mathrm{v})$ Triton-X 100 just before use. Slides were afterwards placed in cold $\left(4^{\circ} \mathrm{C}\right)$ electrophoresis solution ( $\mathrm{pH} 13$ ) for $40 \mathrm{~min}$ to allow DNA-unwinding and enhanced expression of alkali-labile sites. Electrophoresis was for $30 \mathrm{~min}$ at $25 \mathrm{~V}$, in the cold $\left(4{ }^{\circ} \mathrm{C}\right)$, using a Sub-Cell model 96 apparatus (Bio-Rad). Slides were afterwards neutralized in $0.1 \mathrm{M}$ Tris- $\mathrm{HCl}$ buffer $(\mathrm{pH} 7.5)$ for $15 \mathrm{~min}$. All preparatory steps were performed under controlled temperature $\left(\approx 16^{\circ} \mathrm{C}\right)$ to avoid gel lifting from the slides and all solutions and electrophoresis apparatus were kept in the dark and in the cold to minimize accessory DNA degradation. Approximately 100 comets were analysed per slide after staining with $0.02 \mathrm{mg} \mathrm{mL}^{-1}$ ethidium bromide. Comets were analysed using the software CometScore 1.5 (TriTek Corp., Summerduck, USA). The percentage DNA in the tail - one of the most consensual comet metrics - was employed as a direct measure of DNA-SB [25]. Results are expressed in average percentage of total DNA-SB per individual. Erythrocyte vitality was assessed by use of the propidiumiodide test, a fluorochrome that penetrates only dead or damaged cells, and at least $70 \%$ viable cells were observed.

A DMLB microscope adapted for epifluorescence with an EL6000 light source for mercury short-arc reflector lamps was used for both analyses, equipped with an I3 filter (used for acridine-orange staining) and an N2.1 filter (used for ethidiumbromide staining), all from Leica Microsystems.

\subsection{Statistical analysis}

Data were analysed by non-parametric statistics after invalidation of variances' homogeneity of ENA and Comet assay data by the Levene's test. Analysis of variance was performed using the Kruskall-Wallis ANOVA by ranks for overall differences between tests, the Mann-Whitney $U$ test for pairwise comparisons within tests and sampling times and the Spearman rank-order correlations $R$ for sediment contaminants and genotoxicity analyses. The significance level for all analyses was set at 95\% $(\alpha=0.05)$. All statistics were performed with the software Statistica 6.0 (Statsoft Inc., Tulsa, OK, USA)

\section{Results}

Overall mortality at the end of the assay was very different between tests: $2 \%$ for sediment A, $13 \%$ for B and $48 \%$ for C. Replicate effect between tests was found to be non-significant for both ENA and DNA-SB analyses, $p=0.67$ and $p=0.43$, respectively

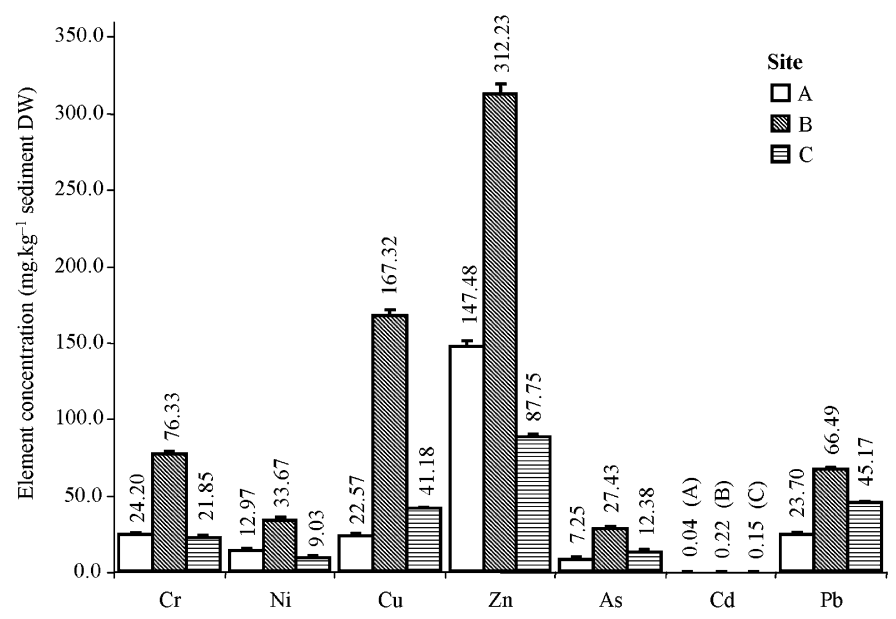

Fig. 2. Concentration of $\mathrm{Cr}, \mathrm{Ni}, \mathrm{Cu}, \mathrm{Zn}, \mathrm{As}, \mathrm{Cd}$ and $\mathrm{Pb}$ in tested sediments. Error bars indicate the standard error. 


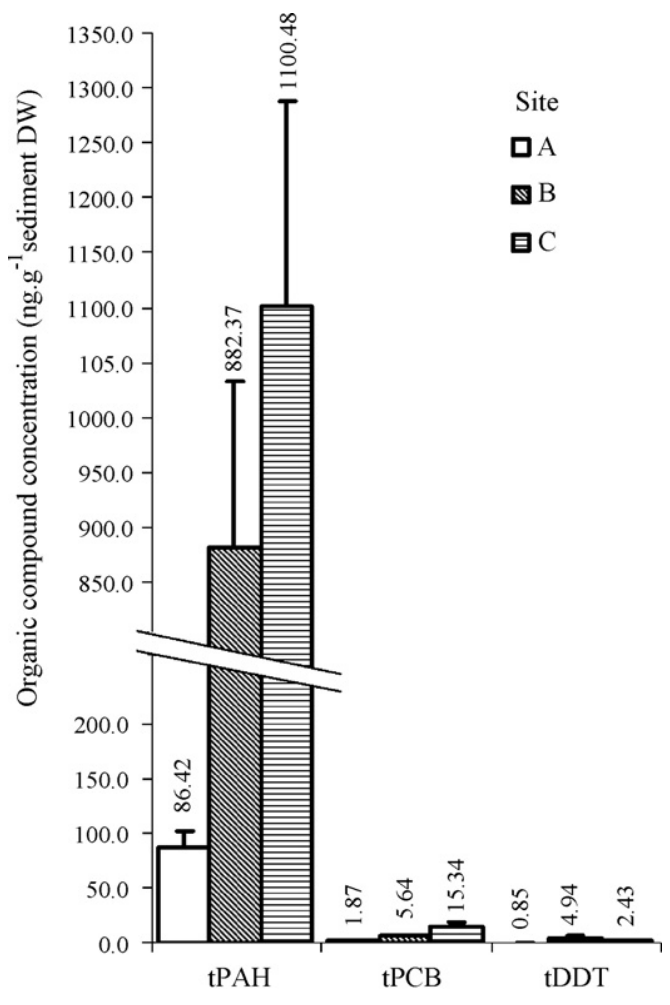

Fig. 3. Concentration of organic contaminants in sediments. Error bars indicate the standard error.

(Kruskall-Wallis $H$ ). Fish standard length and total fresh weightranges were $70 \pm 6 \mathrm{~mm}$ and $4.21 \pm 1.53 \mathrm{~g}$, respectively, at the end of the assays and no significant differences were found between tests and sampling times regarding both measures (Kruskall-Wallis $H$, $p>0.05$ ).

\subsection{Sediment parameters and contaminants}

The sediments from the three sites revealed distinct characteristics (Table 1) and different levels of contamination regarding metallic (Fig. 2) and organic (Fig. 3) contaminants. Sediment A is the least contaminated by organic substances and shows the lowest levels of $\mathrm{Cd}, \mathrm{As}, \mathrm{Cd}$ and $\mathrm{Pb}$. The sediment from this site is essentially sandy, with little organic matter, while sediments $B$ and $C$ present high FF and TOM and lower Eh. Sediment B is the most contaminated with each of the metals studied and also presents high levels of PAHs. Sediment $C$ is essentially contaminated by organic compounds, especially PAHs and PCBs. The main contributions in the PAH contamination in sediments are from 4- and 5-ring PAHs, which in combination represent $73.8 \%$ of tPAH in sediment $A, 70.6 \%$ in $B$ and $67.7 \%$ in C. Penta- and hexa-chlorinated compounds are the most representative PCBs, especially in sediment C (91.1\% relatively to $\mathrm{APCB}$ ). DDT contamination was found to be low at all sites, the main contribution coming from pp'DDT ( $82.4 \%$ in sediment $\mathrm{A}, 88.9 \%$ in B and $48.5 \%$ in C, relatively to tDDT) (Table 2 ).

\subsection{Genotoxicity}

Nuclear buds, lobed nuclei or a combination of these two alterations (Fig. 4) comprised the large majority of ENA observed, with an average of $74.1 \pm 23.8 \%$ of total observed ENA in the most affected individuals (\%ENA $>16 \%$ ). The observed nuclear alterations are in accordance with previous studies using acridine-orange staining [6]. A significant increment in average percentage of ENA was observed for all stations at $T_{28}$, relative to $T_{0}$, but only significant at $\mathrm{T}_{14}$ regarding the test with sediment $\mathrm{C}$ (Fig. 5 ). From $\mathrm{T}_{14}$ to $\mathrm{T}_{28}$ tests $\mathrm{A}$ and $B$ revealed a significant increase in ENA (Mann-Whitney $U$ test, $p<0.05$ and $p<0.01$, respectively), whereas test $C$ showed a less significant increment in average percentage of ENA (Mann-Whitney $U$ test, $p=0.12$ ).

A similar pattern to that obtained from ENA analysis was seen in the Comet assay (Fig. 6), but differences between tests and sampling times were more significant overall. An increment in DNA-SB at $\mathrm{T}_{14}$ compared with $T_{0}$ was found to be significant even for the tests with sediments $A$ and $B$, which was not evident from ENA analysis (Fig. 7). Nevertheless, only test B showed evidence of a significant increase in DNA-SB from $\mathrm{T}_{14}$ to $\mathrm{T}_{28}$ (Mann-Whitney $U$ test, $p<0.05$ ).

Spearman rank-order correlation confirmed sediment PAHs and PCBs of freshly collected sediments to be the variables that influence the increase of genotoxic effects the most , at both $\mathrm{T}_{14}$ and $\mathrm{T}_{28}$. At $\mathrm{T}_{28}$, however, $\mathrm{Cu}, \mathrm{As}, \mathrm{Cd}$ and $\mathrm{Pb}$ were also found positively correlated with both ENA and DNA-SB (Table 3). No significant correlations (Spearman $R, p>0.05$ ) were found between body size (total fresh weight, FW, and SL) and both ENA and DNA-SB.

\section{Discussion and conclusions}

The sediment with higher concentrations of organic contaminants (sediment C) was responsible for faster and stronger

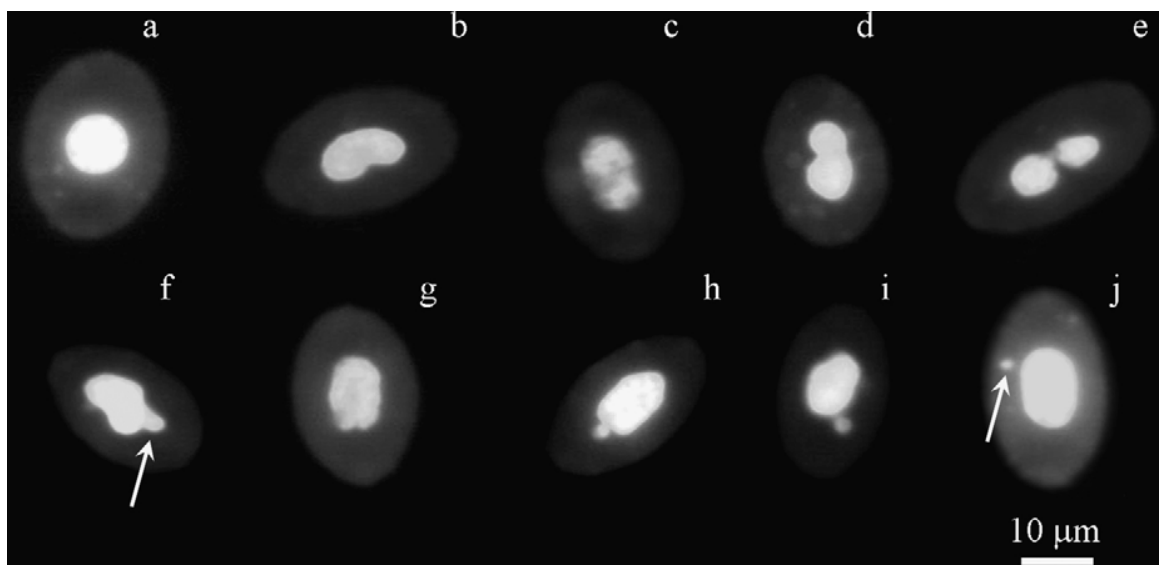

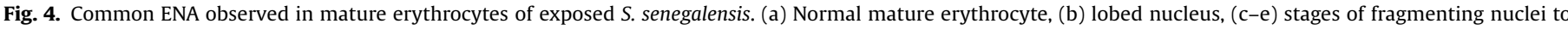

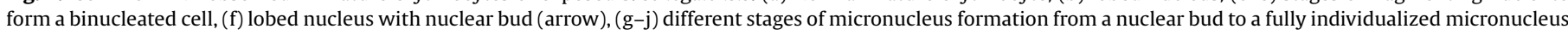
(arrow). 
Table 2

Categorized concentrations of PAHs, PCBs and DDTs in test sediments

\begin{tabular}{|c|c|c|c|}
\hline \multirow[t]{2}{*}{ Substance (CAS number) } & \multicolumn{3}{|c|}{ Concentration in sediment $\left(\mathrm{ng} \mathrm{g}^{-1}\right)$} \\
\hline & A & $\mathrm{B}$ & C \\
\hline \multicolumn{4}{|l|}{ PAHs } \\
\hline \multicolumn{4}{|l|}{ 3-ring } \\
\hline Acenaphthylene (208-96-8) & $11.95 \pm 2.03$ & $81.32 \pm 13.82$ & $83.60 \pm 14.21$ \\
\hline \multicolumn{4}{|l|}{ Acenaphthene (83-32-9) } \\
\hline \multicolumn{4}{|l|}{ Fluorene (86-73-7) } \\
\hline \multicolumn{4}{|l|}{ Phenanthrene (85-01-8) } \\
\hline \multicolumn{4}{|l|}{ Anthracene (120-12-7) } \\
\hline \multicolumn{4}{|l|}{ 4-ring } \\
\hline Fluoranthene (206-44-0) & $39.43 \pm 6.70$ & $395.46 \pm 67.23$ & $479.40 \pm 81.50$ \\
\hline \multicolumn{4}{|l|}{ Pyrene (129-00-0) } \\
\hline \multicolumn{4}{|l|}{ Benz(a)anthracene (56-55-3) } \\
\hline \multicolumn{4}{|l|}{ Chrysene (218-01-9) } \\
\hline \multicolumn{4}{|l|}{ 5-ring } \\
\hline Benzo(b)fluoranthrene (205-99-2) & $24.35 \pm 4.14$ & $227.06 \pm 38.60$ & $266.06 \pm 45.03$ \\
\hline \multicolumn{4}{|l|}{ Benzo(k)fluoranthrene (207-08-9) } \\
\hline \multicolumn{4}{|l|}{ Benzo(e)pyrene (192-97-2) } \\
\hline \multicolumn{4}{|l|}{ Benzo(a)pyrene (50-32-8) } \\
\hline \multicolumn{4}{|l|}{ Dibenzo( $a, h)$ anthracene $(53-70-3)$} \\
\hline \multicolumn{4}{|l|}{ Perylene (198-55-0) } \\
\hline \multicolumn{4}{|l|}{ 6-ring } \\
\hline Indeno(1,2,3-cd)pyrene (193-39-5) & $5.99 \pm 1.02$ & $91.55 \pm 15.56$ & $62.26 \pm 10.58$ \\
\hline \multicolumn{4}{|l|}{ Indeno(1,2,3-cd)pyrene (193-39-5) } \\
\hline \multicolumn{4}{|l|}{ PCBs } \\
\hline \multicolumn{4}{|l|}{ Trichlorinated } \\
\hline CB-18 (37680-65-2) & $0.73 \pm 0.12$ & $0.33 \pm 0.06$ & $0.17 \pm 0.03$ \\
\hline CB-26 (38444-81-4) & & & \\
\hline CB-31 (16862-07-4) & & & \\
\hline Tetrachlorinated & & & \\
\hline CB-44 (41464-39-5) & $0.13 \pm 0.02$ & $0.58 \pm 0.10$ & $0.81 \pm 0.14$ \\
\hline CB-49 (41464-40-8) & & & \\
\hline CB-52 (35693-99-3) & & & \\
\hline Pentachlorinated & & & \\
\hline CB-101 (37680-73-2) & $0.08 \pm 0.01$ & $1.49 \pm 0.25$ & $6.76 \pm 1.15$ \\
\hline CB-105 (37680-73-2) & & & \\
\hline CB-118 (31508-00-6) & & & \\
\hline Hexachlorinated & & & \\
\hline CB-128 (38380-07-3) & $0.43 \pm 0.07$ & $1.57 \pm 0.27$ & $7.22 \pm 1.23$ \\
\hline CB-138 (35065-28-2) & & & \\
\hline CB-149 (38380-04-0) & & & \\
\hline CB-151 (52663-63-5) & & & \\
\hline CB-153 (52663-63-5) & & & \\
\hline Heptachlorinated & & & \\
\hline CB-170 (35065-30-6) & $0.30 \pm 0.05$ & $0.95 \pm 0.16$ & $0.38 \pm 0.06$ \\
\hline CB-180 (35065-29-3) & & & \\
\hline CB-194 (35694-08-7) & & & \\
\hline DDTs & & & \\
\hline DDE (72-55-9) & $0.05 \pm 0.01$ & $0.27 \pm 0.05$ & $0.65 \pm 0.11$ \\
\hline DDD (72-54-8) & $0.10 \pm 0.02$ & $0.28 \pm 0.05$ & $0.60 \pm 0.10$ \\
\hline DDT (50-29-3) & $0.70 \pm 0.12$ & $4.39 \pm 0.74$ & $1.18 \pm 0.20$ \\
\hline
\end{tabular}

Ranges indicate standard error.

genotoxic effects and caused the highest overall mortality, whereas the sediment most heavily contaminated with metals (sediment B) was found to induce genotoxicity more significantly at a later stage and to cause less lethality. Differences between test sediments appear to be linked to the nature of the contamination (organic/metallic). The difference between genotoxic effects of both classes of contaminants may be explained by two factors: (i) the stronger genotoxicity of organic toxicants, especially PAHs and PCBs and (ii) the known inhibitory action of metals towards the cytochrome P450 (CYP) isoenzymes involved in the catabolism of organic compounds.

PAHs like benzo( $a)$ pyrene $(\mathrm{B}(a) \mathrm{P})$, one of the best represented types of PAH in sediments B and, especially, C, are known sediment genotoxicants that have been widely employed in mutagenicity and carcinogenicity studies in vitro, in laboratory assays (using spiked or actual field-collected water and sediments) and in field-collected or laboratory-tested animals, animal cell lines and microorganisms [26]. Studies with benthic fish, especially flatfish, have also become common for research on sediment PAHs [27]. These compounds are potent DNA-SB inducers at low doses: PAHs in water, for instance, have been found to induce DNA damage in fish liver and erythrocytes even at concentrations as low as $0.3-0.5 \mathrm{ppb}[28,29]$. PAHs are known to have severe mutagenic and carcinogenic effects $[26,27]$ by binding to DNA (adduct formation) at specific sites known as xenobiotic response elements (XREs), promoting DNA instability and potentially giving rise to strand breakage, but the xenobiotic-DNA adduct formation is dependent on PAH activation by cytochrome $\mathrm{P} 450$. The liver is the most important organ involved in contaminant 


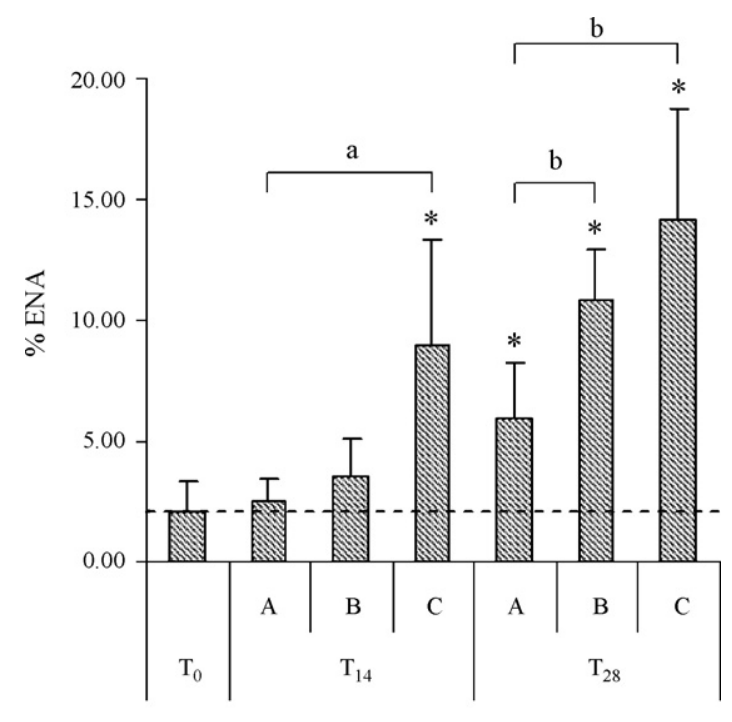

Site and sampling time

Fig. 5. Average percentage of cells showing ENA. Error bars represent 95\% confidence intervals. $\left(^{*}\right)$ indicates differences $\left(p<0.01\right.$, Mann-Whitney $U$ test) from $T_{0}$ (dashed line). a and $\mathrm{b}$ indicate differences between tests (Mann-Whitney $U$ test): $p<0.01$ and $p<0.05$, respectively.

metabolism and for this reason the P450 activity in the liver and genotoxic effects in hepatocytes are commonly surveyed in relation with contamination with PAH and other pollutants. ROS-inducing metabolites and activated PAHs may enter the blood stream and affect blood cells and haemato-poietic organs, e.g., by inducing DNA strand-breakage directly and by formation of xenobiotic-DNA adducts, respectively. For this reason research on peripheral blood and bone marrow is highly relevant. Furthermore, it is likely that blood is rapidly affected by the direct action of contaminants, as it is the main conveyor of xenobiotics.

The nature of the defence mechanisms against PAH contamination may also contribute to explain the observed results regarding DNA-SB. Even though benthic fish species display a fast PAH catabolism upon contamination [30], PAH-DNA adducts in fish liver appear to be repaired slowly [28,31], which may have contributed to a cumulative effect in DNA damage along the assay's timescale, especially in tests of sediment $\mathrm{C}$, where the most significant increase in genotoxicity (even at $\mathrm{T}_{14}$ ) was observed, which may have further compromised the efficiency of DNA repair. On the other hand, genotoxicity caused by PAHs may occur as an effect

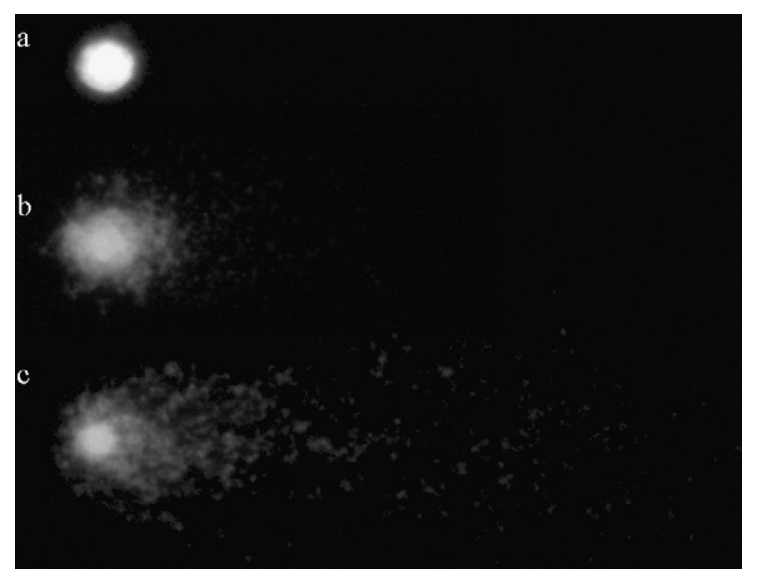

Fig. 6. Comet examples from tested fish: $\approx 0 \%(a), \approx 20 \%$ (b) and $\approx 55 \%$ (c) DNA-SB.

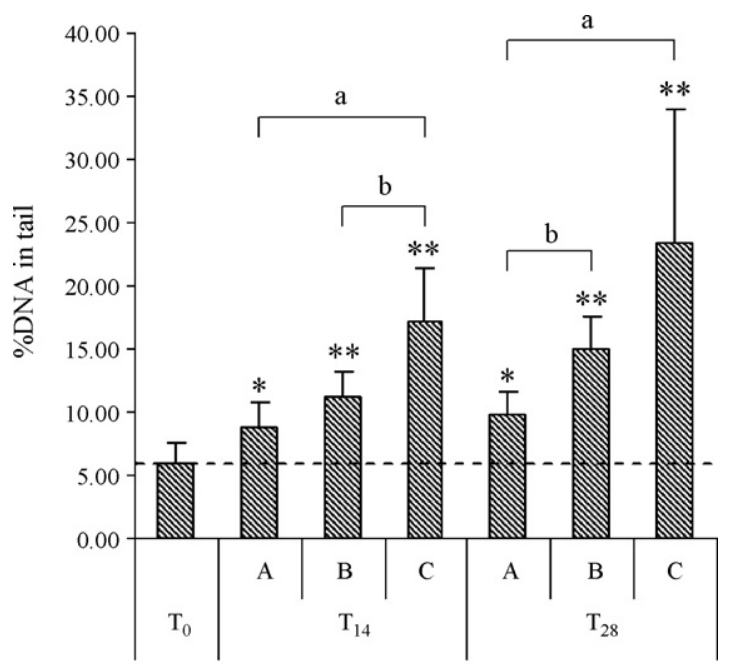

Site and sampling time

Fig. 7. Average percentage of DNA in tail. Error bars represent $95 \%$ confidence intervals. $\left({ }^{*}\right)$ and $\left({ }^{* *}\right)$ indicate differences from $\mathrm{T}_{0}$ (dashed line): $p<0.05$ and $p<0.01$, respectively. $\mathrm{a}$ and $\mathrm{b}$ indicate differences between tests (Mann-Whitney $U$ test): $p<0.01$ and $p<0.05$ respectively.

of overexpression of cytochrome P4501A (CYP1A)-related isoenzymes by (i) activation of the PAHs, e.g., through formation of $\mathrm{PAH}$ quinones [32], which allows them to bind directly to DNA (forming PAH-DNA adducts) and (ii) by formation - during PAH catabolism of ROS, which are responsible for direct DNA base oxidation [33,34]. The combination of these factors may have contributed to a faster induction of genotoxicity, and causing the highest mortality, in the assay with sediment $C$. It is noteworthy, though, that metals in sediment $B$, which also contains high levels of PAH when compared with sediments from site A, may have inhibited P450 activity instead of inducing it, therefore reducing genotoxicity of PAHs by restraining the formation of the highly genotoxic activated PAH metabolites. This is in accordance with previous findings regarding CYP induc-

Table 3

Spearman rank-order correlations for sediment contaminants $\times$ genotoxicity biomarkers (n.s., non-significant)

\begin{tabular}{|c|c|c|c|c|}
\hline & \multicolumn{2}{|l|}{$\%$ ENA } & \multicolumn{2}{|l|}{$\%$ DNA SB } \\
\hline & Spearman $R$ & $p$ & Spearman $R$ & $p$ \\
\hline \multicolumn{5}{|l|}{ T14 } \\
\hline $\mathrm{Cr}$ & - & n. s. & - & n. s. \\
\hline $\mathrm{Ni}$ & - & n. s. & - & n. s. \\
\hline $\mathrm{Cu}$ & - & n. s. & - & n. s. \\
\hline $\mathrm{Zn}$ & - & n. s. & - & n. s. \\
\hline As & - & n. s. & - & n. s. \\
\hline $\mathrm{Cd}$ & - & n. s. & - & n. s. \\
\hline $\mathrm{Pb}$ & - & n. s. & - & n. s. \\
\hline $\mathrm{tPAH}$ & 0.37 & $<0.05$ & 0.51 & $<0.01$ \\
\hline $\mathrm{tPCB}$ & 0.37 & $<0.05$ & 0.51 & $<0.01$ \\
\hline tDDT & - & n. s. & - & n. s. \\
\hline \multicolumn{5}{|l|}{ T28 } \\
\hline $\mathrm{Cr}$ & - & n. s. & - & n. s. \\
\hline $\mathrm{Ni}$ & - & n. s. & - & n. s. \\
\hline $\mathrm{Cu}$ & 0.44 & $<0.01$ & 0.45 & $<0.01$ \\
\hline $\mathrm{Zn}$ & - & n. s. & - & n. s. \\
\hline As & 0.44 & $<0.01$ & 0.45 & $<0.01$ \\
\hline $\mathrm{Cd}$ & 0.44 & $<0.01$ & 0.45 & $<0.01$ \\
\hline $\mathrm{Pb}$ & 0.44 & $<0.01$ & 0.45 & $<0.01$ \\
\hline $\mathrm{tPAH}$ & 0.54 & $<0.001$ & 0.59 & $<0.001$ \\
\hline $\mathrm{tPCB}$ & 0.54 & $<0.001$ & 0.59 & $<0.001$ \\
\hline tDDT & 0.44 & $<0.01$ & 0.45 & $<0.01$ \\
\hline
\end{tabular}


tion by exposure to PAH and metals in the liver of fish and other vertebrates, and showing that metals with high inhibitory capability are $\mathrm{Cd}>\mathrm{As}>\mathrm{Pb}$ and also $\mathrm{Zn}$ and $\mathrm{Cu}$ [35-37]. Since our findings strongly suggest a relationship between overall mortality and genotoxicity, it is likely that a reduction in PAH and PAH metabolites may significantly decrease lethality.

Information is scarce regarding the mechanisms of chromosomal breakage (leading to the formation of micronuclei and other nuclear abnormalities), but PAHs in water have since long been described as strong inducers of micronuclei in fish erythrocytes [38], as well as PCBs and DDTs [39]. Exposure to complex mixtures of organic contaminants such as petroleum effluents in water has also been found responsible for ENA induction in fish [5]. Due to the chromosomal (clastogenic) nature of ENA (as opposed to the nucleotide-related nature of DNA-SB), research has essentially focused on the effects of organic compounds such as colchicine (see, e.g., [40]), known for its effect on cell division by affecting the spindle apparatus. Our results show, nevertheless, that PAHs and PCBs are linked to ENA and, therefore, that these substances are capable of inducing chromosome-level genotoxicity in parallel to DNA-SB, and consequently are similarly related to the observed lethality. No effect was detected for DDTs, most likely due to the low concentrations found in all tested sediments.

Some metals (like Cd) and metalloids (like As) are also known as strongly genotoxic substances but, along with $\mathrm{Pb}$ and $\mathrm{Cu}$, they were observed to have a slower, but almost as strong effect on ENA and DNA-SB at $\mathrm{T}_{28}$. This was even the case for sediment $\mathrm{B}$, which presents a lower level of contamination by organic compounds than sediment $\mathrm{C}$. This delayed but strong effect may be related to the difference between the mechanisms of metal-and organic-induced genotoxicity and a slower release of metals from sediments during the assay. Metal genotoxicity regarding DNA-SB seems to be more directly linked to the formation of ROS, e.g., induced by metallic metabolites like some methylated forms of As [41].

The effects of metallic ions on the formation of ENA are well known and long established for toxicology tests in vitro and in vivo. $\mathrm{Cd}, \mathrm{As}, \mathrm{Pb}$ and $\mathrm{Cu}$ are strong ENA inducers $[3,7,42,43]$. Nevertheless, the genotoxicity mechanisms of ENA formation as a result of metal exposure are not yet fully understood and may vary with different metals. Some evidence points to a correlation of ROS and antioxidant enzymes with micronuclei upon As exposure (see, e.g., [44]), but it is generally accepted that induction of micronuclei is essentially dependent on the role of xenobiotics on DNA replication and cell division [9], which may be a reason why the Comet assay appeared to be more sensitive at $\mathrm{T}_{14}$, since direct DNA-SB may be more rapidly induced. The interactions between organic and metallic contaminants on ENA are unclear, but recent findings suggest that $\mathrm{B}(a) \mathrm{P}$-mediated induction of micronuclei in mouse bone-marrow may be enhanced by simultaneous exposure to As, but not Cd [45]. Our results, nevertheless, suggest a possible inhibitory action of metals on organic contaminant-induced ENA, as observed for DNA-SB.

Sediments B and C have higher levels of TOM and FF, while metals are known to have a high affinity for sediment organic matter and FF $[46,47]$. The bioavailability of some metals may have increased progressively during the assays due to alterations of the redox status of the sediments and extensive re-suspension of sediments caused by the scavenging activities of the fish. It is noteworthy that highly toxic metals like Cd may have a prolonged availability in the water column after sediment re-suspension [48]. Sediments from site $\mathrm{B}$ and, even more so, site $\mathrm{C}$ had more reducing conditions (lower Eh) that, combined with re-suspension, should have favoured the release of both organic and metallic contaminants [49] and thus contributed to the much stronger genotoxic effects and lethality of sediments B and C in comparison with those of sediment A. Genotoxicity may have in fact been enhanced in all three tests (hence a significant DNA-SB increase in fish exposed to sediment $A$ from $T_{0}$ to $T_{14}$ ) just by a combination of low Eh and re-suspension during the assays, which may have favoured the bio-availability of the contaminants.

The metal concentrations in the three sediments are in accordance with previous contaminant profiles obtained for the study area [15], but concentrations measured in the present study were overall lower. Nonetheless, resuspension and alterations of the sediment parameters during the assays render it difficult to extrapolate risk assessment from sediment contaminants to the natural environment, due to alterations in bio-availability and the presence of other contaminants, an issue that has been established as being of special relevance with respect to the combined presence of metallic and organic contaminants [50]. A comparison with previous data from sediments collected from approximately the same sites revealed that tPAHs decreased tenfold for all sites, but tPCBs increased tenfold. As in the present study, this comparison identified the PAHs as the type of toxicant most likely implicated in a significant induction in DNA-SB in the test organisms [51]. These findings confirm the high genotoxicity of PAHs and their relevance among the organic contaminants in the different sediments surveyed, both with respect to concentration and toxicity. Other studies have found a probable relation between sediment PAHs (i.e., the most representative contaminants) and genotoxicity in benthic fish [52], but research on natural sediments that integrates both organic and metallic contaminants and their interactions on genotoxicity is essentially lacking. This is yet another factor that renders it difficult to assess the actual genotoxic potential of sediment mixtures of contaminants in fish and to define toxicity thresholds.

In general, the results from both sediment characterization and biomarker analyses reflect the expected contamination patterns for the three stations. Concentration of contaminants in sediments from sites $B$ and $C$ are likely to be related with proximity of pollutant "hotspots", namely from urban and port facilities (metals in B) and industry, especially chemical plants and runoffs from agriculture grounds upstream likely to be contaminated with fertilizers and pesticides (organic contaminants in C). Furthermore, higher levels of FF and TOM in sediments B and C may have allowed higher accumulation of contaminants, later released during the assays.

The use of ENA (analysed with fluorescence techniques) and DNA-SB (measured with the Comet assay) as genotoxicity biomarkers proved successful in the context of a practical biomonitoring procedure for contaminated estuarine sediments and also allowed assessment of the relative genotoxic effects of metals and organic contaminants in sediments. The Comet assay appeared to be a more sensitive method than ENA analysis, since it reflected better the contamination pattern and the observed lethality from the test sediments, contradicting some of the results from others, who have questioned the sensitivity and applicability of the Comet assay as a biomonitoring tool for aquatic contamination [14,53]. It is concluded that genotoxicity assessment in peripheral blood cells of a benthic vertebrate such as $S$. senegalensis is a valuable tool for biomonitoring estuarine sediments contaminated with mixed classes of substances.

\section{Conflict of interest}

None.

\section{Acknowledgements}

The present research was approved by the Portuguese Science and Technology Foundation (FCT) and POCTI (Programa 
Operacional Ciência, Tecnologia e Inovação, research project ref. POCTI/AMB 57281/104) and financed by FEDER (European Fund for Regional Development). P. M. Costa is supported by a FCT PhD grant (SFRH/BD/28465/2006). The authors would like to thank T. Neuparth (IMAR), APSS (Administração dos Portos de Setúbal e Sesimbra, SA) and RNES (Reserva Natural do Estuário do Sado) for the logistic support and Pedro Pousão (Estação Piloto de Piscicultura, INRB/IPIMAR-Cripsul).

\section{References}

[1] D. Sul, E. Oh, H. Im, M. Yang, C.-W. Kim, E. Lee, DNA damage in T- and B-lymphocytes and granulocytes in emission inspection and incineration workers exposed to polycyclic aromatic hydrocarbons, Mutat. Res. 538 (2003) 109-119.

[2] N. Sailaja, M. Chandrasekhar, P.V. Rekhadevi, M. Mahbooba, M.F. Rahmana, S.B. Vuyyuri, K. Danadevi, S.A. Hussain, P. Grover, Genotoxic evaluation of workers employed in pesticide production, Mutat. Res. 609 (2006) 74-80.

[3] F. Ayllon, E. García-Vázquez, Induction of micronuclei and other nuclear abnormalities in European minnow Phoxinus phoxinus and mollie Poecilia latipinna: an assessment of the fish micronucleus test, Mutat. Res. 467 (2000) 177-186.

[4] T. Çavaş, S. Ergene-Gözükara, Induction of micronuclei and nuclear abnormalities in Oreochromis niloticus following exposure to petroleum refinery and chromium processing plant effluents, Aquat. Toxicol. 74 (2005) 264-271.

[5] S. Ergene, T. Çavaş, A. Çelik, N. Köleli, F. Kaya, A. Karahan, Monitoring of nuclear abnormalities in peripheral erythrocytes of three fish species from the Goksu Delta (Turkey): genotoxic damage in relation to water pollution, Ecotoxicology 16 (2007) (2007) 385-391.

[6] P.M. Costa, M.H. Costa, Genotoxicity assessment in fish peripheral blood: a method for a more efficient analysis of micronuclei, J. Fish Biol. 71A (2007) 148-151.

[7] T. Çavaş, N.B. Garanko, V.V. Arkhipchuk, Induction of micronuclei and binuclei in blood, gill and liver cells of fishes subchronically exposed to cadmium chloride and copper sulphate, Food Chem. Toxicol. 43 (2005) 569-574.

[8] J. Baršienè, V. Dedonytė, A. Rybakovas, L. Andreikènaitè, O.K. Andersen, Investigation of micronuclei and other nuclear abnormalities in peripheral blood and kidney of marine fish treated with crude oil, Aquat. Toxicol. 78S (2006) S99-S104.

[9] M. Nikinmaa, How does environmental pollution affect red blood cell function in fish? Aquat. Toxicol. 22 (1992) 227-238.

[10] N.P. Singh, M.T. McCoy, R.R. Tice, E.L. Schneider, A simple technique for quantitation of low levels of DNA damage in individual cells, Exp. Cell Res. 175 (1988) 184-191.

[11] J. Blasiak, A. Trzeciak, Single cell gel electrophoresis (Comet Assay) as a tool for environmental biomonitoring. An example of pesticides, Pol. J. Environ. Stud. 7 (1998) 189-194.

[12] S.R. Desai, X.N. Verlecar, Nagarajappa, U. Goswami, Genotoxicity of cadmium in marine diatom Chaetoceros tenuissimus using the alkaline Comet Assay, Ecotoxicology 15 (2006) 359-363.

[13] G.M. Alink, J.T.K. Quik, E.J.M. Penders, A. Spenkelink, S.G.P. Rotteveel, J.L. Maas, W. Hoogenboezem, Genotoxic effects in the eastern mudminnow (Umbra pygmaea L.) after exposure to Rhine water, as assessed by use of the SCE and Comet assays: a comparison between 1978 and 2005, Mutat. Res. 631 (2007) 93-100.

[14] G. Wirzinger, L. Weltje, J. Gercken, H. Sordyl, Genotoxic effects in field-collected three-spined sticklebacks (Gasterosteus aculeatus L.): a suitable biomonitoring tool? Mutat. Res. 628 (2007) 19-30.

[15] S. Caeiro, M.H. Costa, T.B. Ramos, F. Fernandes, N. Silveira, A. Coimbra, G. Medeiros, M. Painho, Assessing heavy metal contamination in Sado Estuary sediment: an index analysis approach, Ecol. Indicators 5 (2005) 151-169.

[16] P.M. Costa, T. Repolho, S. Caeiro, M.E. Diniz, I. Moura, M.H. Costa, Modelling metallothionein induction in the liver of Sparus aurata exposed to metal-contaminated estuarine sediments, Ecotox. Environ. Safe (2007), doi:10.1016/j.ecoenv.2007.05.012.

[17] H.N. Cabral, Distribution and abundance patterns of flatfishes in the Sado Estuary, Portugal, Estuaries 23 (2000) 351-358.

[18] H.N. Cabral, Comparative feeding ecology of sympatric Solea solea and S. senegalensis, within the nursery areas of the Tagus estuary, Portugal, J. Fish Biol. 57 (2000) 1550-1562.

[19] R. Sá, C. Bexiga, L. Vieira, P. Veiga, K. Erzini, Diets of the sole Solea vulgaris Quansel, 1806 and Solea sengalensis Kaup, 1858 in the lower estuary of the Guadiana River (Algarve, southern Portugal): preliminary results, Bol. Inst. Esp. Oceanogr. 19 (2003) 505-508.

[20] I. Riba, M.C. Casado-Martínez, J. Blasco, T.A. DelValls, Bioavailability of heavy metals bound to sediments affected by a mining spill using Solea senegalensis and Scrobicularia plana, Mar. Environ. Res. 58 (2004) 395-399.

[21] M. Caetano, N. Fonseca, R. Cesário, C. Vale, Mobility of Pb in salt marshes recorded by total content and stable isotopic signature, Sci. Total Environ. 380 (2007) 84-92.
[22] M. Martins, A.M. Ferreira, C. Vale, The influence of Sarcocornia fruticosa on retention of PAHs in salt marshes sediments (Sado estuary, Portugal), Chemosphere 71 (2008) 1599-1606.

[23] A.M. Ferreira, M. Martins, C. Vale, Influence of diffuse sources on levels and distribution of polychlorinated biphenyls in the Guadiana River estuary, Portugal, Mar. Chem. 89 (2003) 175-184.

[24] M. Fenech, W.P. Chang, M. Kirsch-Volders, N. Holland, S. Bonassi, E. Zeiger, HUMN project: detailed description of the scoring criteria for the cytokinesisblock micronucleus assay using isolated human lymphocyte cultures, Mutat. Res. 534 (2003) 65-75.

[25] R.F. Lee, S. Steinert, Use of the single cell gel electrophoresis/comet assay for detecting DNA damage in aquatic (marine and freshwater) animals, Mutat. Res. 544 (2003) 43-64.

[26] G. Chen, P.A. White, The mutagenic hazards of aquatic sediments: a review, Mutat. Res. 567 (2004) 151-225.

[27] M.S. Myers, L.L. Johnson, T.K. Collier, Establishing the causal relationship between polycyclic aromatic hydrocarbon (PAH) exposure and hepatic neoplasms and neoplasia-related liver lesions in English sole (Pleuronectes vetulus), Hum. Ecol. Risk Assess 9 (2003) 67-94.

[28] E. Aas, T. Baussant, L. Balk, B. Liewenborg, O.K. Andersen, PAH metabolites in bile, cytochrome P4501A and DNA adducts as environmental risk parameters for chronic oil exposure: a laboratory experiment with Atlantic cod, Aquat. Toxicol. 51 (2000) 241-258.

[29] T. Neuparth, J.W. Bickham, C.W. Theodorakis, F.O. Costa, M.H. Costa, Endosulfaninduced genotoxicity detected in the gilthead seabream, Sparus aurata L., by means of flow cytometry and micronuclei assays, Bull. Environ. Contam. Toxicol. 76 (2006) 242-248.

[30] U. Varanasi, D.J. Gmur, Hydrocarbons and metabolites in English sole (Parophrys vetulus) exposed simultaneously to $\left[{ }^{3} \mathrm{H}\right]$ benzo $(a)$ pyrene and $\left[{ }^{14} \mathrm{C}\right]$ naphthalene in oil-contaminated sediment, Aquat. Toxicol. 1 (1981) 49-67.

[31] S.A. Ploch, L.C. King, M.J. Kohan, R. Di Giulio, Comparative in vitro and in vivo benzo(a)pyrene-DNA adduct formation and its relationship to CYP1A activity in two species of ictalurid catfish, Toxicol. Appl. Pharm. 149 (1998) 90-98.

[32] L. Flowers-Geary, W. Bleczinski, R.G. Harvey, T.M. Penning, Cytotoxicity and mutagenicity of polycyclic aromatic hydrocarbon 0 -quinines produced by dihydrodiol dehydrogenase, Chem. Biol. Interact. 99 (1996) 66-72.

[33] L. Risom, P. Møller, S. Loft, Oxidative stress-induced DNA damage by particulate air pollution, Mutat. Res. 592 (2005) 119-137.

[34] T. Hansen, A. Seidel, J. Borlak, The environmental carcinogen 3nitrobenzanthrone and its main metabolite 3-aminobenzanthrone enhance formation of reactive oxygen intermediates in human A549 lung epithelial cells, Toxicol. Appl. Pharm. 221 (2007) 222-234.

[35] B.J. Brüschweiler, F.E. Würgler, K. Fent, Inhibitory effects of heavy metals on cytochrome P4501A induction in permanent fish hepatoma cells, Arch. Environ. Con. Tox. 31 (1996) 475-482.

[36] D.D. Vakharia, N. Liu, R. Pause, M. Fasco, E. Bessette, Q-.Y. Zhang, L.S. Kaminsky, Polycyclic aromatic hydrocarbon/metal mixtures: effect on PAH induction of CYP1A1 in human HEPG2 cells, Drug Metab. Dispos. 29 (2001) 999-1006.

[37] N.A. Lewis, T.D. Williams, J.K. Chipman, Functional analysis of a metal response element in the regulatory region of flounder cytochrome P450 1A and implications for environmental monitoring of pollutants, Toxicol. Sci. 92 (2006) 387-393.

[38] J.E. Hose, J.B. Hannah, H.W. Puffer, M.L. Landolt, Histologic and skeletal abnormalities in benzo(a)pyrene-treated rainbow trout alevins, Arch. Environ. Con. Tox. 13 (1984) 675-684.

[39] J.E. Hose, J.N. Cross, S.G. Smith, D. Diehl, Elevated circulated erythrocyte micronuclei in fishes from contaminated sites off southern California, Mar. Environ. Res. 22 (1987) 167-176.

[40] A. Rodriguez-Cea, F. Ayllon, E. García-Vazquez, Micronucleus test in freshwater fish species: an evaluation of its sensitivity for application in field surveys, Ecotox. Environ. Safe 56 (2003) 442-448.

[41] E. Soto-Reyes, L.M. Del Razo, M. Valverde, E. Rojas, Role of the alkalilabile sites, reactive oxygen species and antioxidants in DNA damage induced by methylated metabolites of inorganic arsenic, BioMetals 18 (2005) 493-506.

[42] T.W. Gebel, Genotoxicity of arsenical compounds, Int. J. Hyg. Envir. Heal. 203 (2000) 249-262.

[43] J. Palus, K. Rydzynski, E. Dziubaltowska, K. Wyszynska, A.T. Natarajan, R. Nilsson, Genotoxic effects of occupational exposure to lead and cadmium, Mutat. Res. 540 (2003) 19-28.

[44] T.S. Wang, Y.F. Shy, Y.C. Liu, K.Y. Jan, H. Wang, Glutathione peroxidase and catalase modulate the genotoxicity of arsenite, Toxicology 121 (1997) 229-237.

[45] D. Lewińska, J. Arkusz, M. Stańczyk, J. Palus, E. Dziubałtowska, M. Stępnik, Comparison of the effects of arsenic and cadmium on benzo(a)pyreneinduced micronuclei in mouse bone-marrow, Mutat. Res. 632 (2007) 37-43.

[46] V.G. Caccia, F.J. Sillero, A. Palanques, The distribution of trace metals in Florida Bay sediments, Mar. Pollut. Bull. 46 (2003) 1420-1433.

[47] A.M. Mota, P. Cruz, C. Vilhena, M.L.S. Gonçalves, Influence of the sediment on lead speciation in the Tagus estuary, Water Res. 39 (2005) 1451-1460.

[48] M. Caetano, M.J. Madureira, C. Vale, Metal contaminated remobilisation during resuspension of anoxic contaminated sediment: short-term laboratory study, Water Air Soil Pollut. 143 (2003) 23-40. 
[49] J. Eggleton, K.V. Thomas, A review of factors affecting the release and bioavailability of contaminants during sediment disturbance events, Environ. Int. 30 (2004) 973-980.

[50] R.J. Woodhead, R.J. Law, P. Matthiessen, Polycyclic aromatic hydrocarbons in surface sediments around England and Wales, and their possible biological significance, Mar. Pollut. Bull. 38 (1999) 773-790.

[51] T. Neuparth, A.D. Correia, F.O. Costa, G. Lima, M.H. Costa, Multi-level assessment of chronic toxicity of estuarine sediments with the amphipod Gammarus locusta. I. Biochemical endpoints, Mar. Environ. Res. 60 (2005) 69-91.
[52] M.F. Kilemade, M.G.J. Hartl, D. Sheehan, C. Mothersill, F.N.A.M. van Pelt J. O'Halloran, N.M. O'Brien, Genotoxicity of field-collected inter-tidal sediments from Cork Harbor, Ireland, to juvenile turbot (Scophthalmus maximus L.) as measured by the Comet assay, Environ. Mol. Mutagen. 44 (2004) $56-64$.

[53] V. Bombail, D. Aw, E. Gordon, J. Batty, Application of the comet and micronucleus assay to butterfish (Phollis gunnellus) erythrocytes from the Firth of Forth, Scotland, Chemosphere 44 (2001) 383-392. 